\title{
Determination of Tetracycline Antibiotic Residues in Edible Swine Tissues by Liquid Chromatography with Spectrofluorometric Detection and Confirmation by Mass Spectrometry
}

\author{
Angelina Pena $,{ }^{*},{ }^{\dagger}$ Celeste M. Lino,${ }^{\dagger}$ Rosa Alonso, ${ }^{\ddagger}$ And Damia Barceló \\ Group of Bromatology, Center of Pharmaceutical Studies, University of Coimbra, Coimbra, Portugal, \\ and Department of Environmental Chemistry, Chemical and Environmental Research Institute of \\ Barcelona (IIQAB), Consejo Superior de Investigaciones Científicas (CSIC), Barcelona, 08034, Spain
}

\begin{abstract}
A sensitive and specific method is described for the simultaneous determination of oxytetracycline, tetracycline (TC), and chlortetracycline residues in edible swine tissues, by combining liquid chromatography with spectrofluorometric and mass spectrometry detection. The procedure involved a preliminary extraction with EDTA-Mcllvaine buffer acidified at $\mathrm{pH} 4.0$, followed by solid-phase extraction cleanup using a polymeric sorbent. The liquid chromatography analysis was performed with spectrofluorometric detection after postcolumn derivatization with magnesium ions. The limits of quantification were $50 \mu \mathrm{g} / \mathrm{kg}$ for muscle and $100 \mu \mathrm{g} / \mathrm{kg}$ for kidney tissues. The recovery values were greater than $77.8 \%$ for muscle and $65.1 \%$ for kidney. The method has been successfully used for the quantification of tetracyclines in swine tissues samples. The selective liquid chromatography mass spectrometric analysis for confirmation of oxytetracycline in one positive swine muscle sample was made by atmospheric pressure chemical ionization (APCI). The APCl mass spectra of the TCs gave the protonated molecular ion and two typical fragment ions, required for their confirmation in single ion monitoring scan mode in animal tissues.
\end{abstract}

KEYWORDS: Tetracyclines; swine tissues; liquid chromatography; spectrofluorometric detection; mass spectrometric detection

\section{INTRODUCTION}

In recent years, concerns about the use of antimicrobial products in food-producing animals have focused on human food safety because foods of animal origin are vehicles of foodborne disease in humans. The selection of drug-resistant bacterial populations is a consequence of exposure to antimicrobial drugs and can occur from human and animal uses (1).

Tetracyclines (TCs), including tetracycline (TC), oxytetracycline (OTC), and chlortetracycline (CTC), are broad-spectrum antibiotics widely used in modern animal husbandry and may result in unsafe TC residues in animal-derived food products. Since they could represent a risk for the consumer health, the European Union (EU) established its maximum residue limits (MRLs) for muscle and kidney tissues at $100 \mu \mathrm{g} / \mathrm{kg}$ and 600 $\mu \mathrm{g} / \mathrm{kg}$, respectively (2).

It is, therefore, of great interest to develop analytical procedures capable of determining accurately animal tissue concentrations of tetracyclines and to evaluate their presence

* To whom correspondence should be addressed. Tel: 00351239 859994. Fax: 00351239827126. E-mail: apena@ci.uc.pt.

University of Coimbra.

$\div$ IIQAB-CSIC in edible animal products because of demands from the EU to protect human health.

Several methods have been reported for the analysis of TCs in various biological and pharmaceutical matrixes (3-5). Among them, different methods for the extraction and analysis of TCs consider their high propensity for forming chelation complexes.

While it is possible to achieve success with reversed-phase octadecyl $\left(\mathrm{C}_{18}\right)$ cartridges $(6)$, some limitations found it difficult to work. TCs chelate to metal ions and bind with the silanol groups present in silica sorbents, and their recoveries varied drastically depending on the supplier of SPE cartridges and even from the same supplier $(7-8)$.

Metal-chelating affinity chromatography (MCAC) has also been used for the cleanup of food extracts of tetracyclines (910). However, an additional desalting step of eluent from the MCAC column is required prior to analysis by liquid chromatography-gas chromatography (LC-MS). Carson et al. (11) used MCAC as an extraction and concentration step, followed by desalting and further concentration using polymeric cartridges, before LC-MS analysis. However, this procedure is complex and time-consuming.

Cheng et al. (12) present a more simple method for tetracyline analysis in porcine serum using a recently developed cartridge 
containing a macroporous polymer, poly(divinylbenzene- $\mathrm{Co}-\mathrm{N}$ vinylpirrolidone). These sorbent advantages include no impact of sorbent drying and no silanol interaction and improved recovery for polar and nonpolar compounds in complex matrixes over reversed silica-based sorbents. Also, Zhu et al. (13) selected this sorbent for routine analysis of TCs in groundwater and lagoon water samples and Pena and co-workers (14-15) in salmon muscle and honey, because of the simplicity and ruggedness of the method relative to the $\mathrm{C}_{18}$ sorbent.

Several reports on LC analysis of TCs using different detection modes have been published, namely, fluorescence detection of TCs, which is more specific and sensitive than UV detection, has been reported in several papers (16-17). Mass spectrometry detection using thermospray (TSP) (18), particle beam (PB) (19), fast atom bombardment (FAB) (20), atmospheric pressure chemical ionization (APCI) (21), and electrospray ionization (ESI) (22) are described in the scientific literature. Although ESI mass spectra of TCs were obtained with high sensitivity for standard solutions, it is difficult to distinguish the ions originating from the sample matrixes and the ions of TCs, when residual TCs in sample animal tissues were analyzed (23). Oka et al. (24), Zhu et al. (13), and Eeckhout et al. (25) overcome this problem by using ESI tandem mass spectrometry, a more sophisticated and expensive analytical equipment for increasing analytical sensitivity and selectivity in complex matrixes.

An analytical procedure for the determination of tetracyclines in swine muscle and kidney tissues was developed. The method included extraction of analytes from muscle and kidney swine samples into McIlvaine-EDTA buffer acidified at $\mathrm{pH}$ 4.0, according to Oka et al.'s procedure (26), followed by solidphase extraction cleanup using a polymeric sorbent coated cartridge, Oasis HLB. Because TCs produce strong fluorescence with metal ions, the LC analysis was performed with spectrofluorometric detection after postcolumn derivatization with magnesium ions. In this paper, the confirmation analysis in positive samples was performed by APCI LC-MS in positive ion mode detection as confirmatory method to accomplish the criteria established by the Commission Decision 93/256/EEC (27). The APCI mass spectra of the three TCs gave the protonated molecular ion and two structurally fragment ions, required for their confirmation in selected ion monitoring mode (SIM) in animal tissues for regulatory purposes (28-29).

\section{MATERIALS AND METHODS}

Chemicals and Materials. Oxytetracycline (OTC), tetracycline (TC), and chlortetracycline (CTC) were obtained from Sigma Chemical (Madrid, Spain). LC grade acetonitrile and methanol were purchased from Carlo Erba (Milan, Italy). Reagent grade anhydrous disodium sodium phosphate, citric acid, trifluoroacetic acid (TFA), trichloroacetic acid (TCA), disodium ethylenediamine tetraacetate $\left(\mathrm{Na}_{2}\right.$ EDTA), and sodium hydroxide were obtained from Merck (Darmstadt, Germany).

Distillation and passage were through Milli-Q System (Millipore, Bedfore, United States) purified water. All solvents and solutions used in this study were filtered through a $0.2 \mu \mathrm{m}$ filter under vacuum and were degassed by ultrasonication before LC analysis.

Oasis HLB extraction cartridge was $6 \mathrm{~cm}^{3} / 200 \mathrm{mg}$ (Waters Corporation, United States).

Standards, Buffer, and Mobile-Phase Preparation. Individual methanolic stock standard solutions of OTC, TC, and CTC were prepared at a concentration of $1 \mathrm{mg} / \mathrm{mL}$, into a volumetric flask, and were stored at $-20{ }^{\circ} \mathrm{C}$ in brown glass vials for a maximum period of 1 month. The working solutions were a mixture of the tetracyclines prepared by serial dilutions of the stock solution in methanol and were stored in brown glass vials at $4{ }^{\circ} \mathrm{C}$. These solutions were prepared daily immediately before use and were always kept at $4{ }^{\circ} \mathrm{C}$ protected from light.
The mobile phases used for spectrofluorometric and mass spectrometric analysis were a mixture of acetonitrile $-0.01 \mathrm{M}$ oxalic acid (aq $\mathrm{pH} 2.0$ ) 30:70 and acetonitrile-0.01 $\mathrm{M}$ trifluoroacetic acid (aq pH 2.0) 20:80, respectively. The Mcllvaine buffer EDTA solution was prepared weekly as previously described (30). All glassware was cleaned with Extran MA 03 (Merck, Germany):water (10\% v/v), was rinsed in concentrated acid-dichromate solution, was washed thoroughly with tap water, was rinsed with deionized water, and was dried at $80{ }^{\circ} \mathrm{C}$.

Extraction Procedure. Muscle and kidney swine samples were obtained from local butcher shops. Samples were homogenized using a domestic food blender and were stored at $-20^{\circ} \mathrm{C}$ until analysis. The entire extraction-cleanup procedure and chromatographic analysis should be completed in 1 day.

To $5.0 \mathrm{~g}$ amount of homogenized sample, weighed into $50 \mathrm{~mL}$ polypropylene centrifuge tube, was added $20 \mathrm{~mL}$ of $\mathrm{pH} 4.0 \mathrm{Na}_{2}$ EDTA McIlvaine buffer solution, which was vortex-mixed for $2 \mathrm{~min}$. The tubes were then shaken $10 \mathrm{~min}$ on a flatbed shaker at high speed and were sonicated $15 \mathrm{~min}$ in an ultrasonication bath. The samples were immersed in an ice/salt bath during ultrasonic processing. The tubes were centrifuged $10 \mathrm{~min}$ at $2500 \mathrm{~g}$, and the supernatants were decanted carefully into a clean second centrifuge tube. Two more extractions were effectuated with $20 \mathrm{~mL}$ and $10 \mathrm{~mL}$ of $\mathrm{pH} 4.0 \mathrm{Na}_{2}$ EDTA McIlvaine buffer solution, and we repeated all steps until the supernatants from all three extractions were collected in the second tube. The combined supernatants were vortex-mixed with $2 \mathrm{~mL}$ of $20 \%$ trichloroacetic acid for $2 \mathrm{~min}$, were centrifuged $15 \mathrm{~min}$ at $2500 \mathrm{~g}$, and were filtered through $90 \mathrm{~mm}$ Whatman $\mathrm{N}^{\circ} 541$ filter paper with a plug of glass wool. The cartridges Oasis HLB were conditioned with methanol $(3 \mathrm{~mL})$ and water $(2 \mathrm{~mL})$. After extraction, the cartridges were flushed with $2 \mathrm{~mL}$ of $5 \%$ aqueous methanol and were eluted using $2 \mathrm{~mL}$ of $1 \%$ TFA in methanol. The eluates were evaporated to $0.5 \mathrm{~mL}$ under gentle nitrogen stream in a water bath at $30{ }^{\circ} \mathrm{C}$ and were kept at $4{ }^{\circ} \mathrm{C}$ just before injection in the chromatographic system to avoid degradation. All the aforementioned steps were conducted in subdued light.

A blank and one fortification assay were included in each analytical run to check for interferences (e.g., coeluting substances) and to control the accuracy.

Apparatus and Operation Conditions. The analysis by LC with spectrofluorometric detection was performed as previously described (14-15).

A liquid chromatograph HP 1090 (Hewllet Packard, United States) equipped with a mass spectrometer detector HP 1100 MSD (Hewllet Packard, United States), a DAD detector, an injector HP 1100, and a computer ultra VGA 1280 HP (Hewllet Packard, United States) controlled by software HP ChemStation (Hewllet Packard, United States) was used. The HPLC column used was an Inertsil ODS-2 (250 $\times 2 \mathrm{~mm}$ i.d., $5 \mu \mathrm{m}$ ) (Macherey-Nagel, Duren, Germany). The mobilephase flow used at room temperature was $0.3 \mathrm{~mL} / \mathrm{min}$.

The APCI interface, set at a nebulizer gas pressure (nitrogen) of 60 psi, was operated in positive ion mode. A vaporizer temperature of $450{ }^{\circ} \mathrm{C}$ and a corona discharge voltage of $6 \mu \mathrm{A}$ were used. The voltages of the capillary and of the fragmentor were set at $4000 \mathrm{~V}$ and $90 \mathrm{~V}$, respectively. The drying gas (nitrogen) was adjusted to a constant flow rate of $10 \mathrm{~L} / \mathrm{min}$ and to a temperature of $325^{\circ} \mathrm{C}$.

The autosampler was programmed to inject $100 \mu \mathrm{L}$ aliquots of standard solutions containing each TC, needed to generate the calibration curve, following the sample extracts. The standard solutions and samples were determined triplicate. Between the injections of standards and of samples and between injections of each sample, a blank injection of methanol was made.

\section{RESULTS AND DISCUSSION}

Liquid Chromatography-Spectrofluorometric Detection. The isocratic analysis with a mobile phase, consisting in acetonitrile- $0.01 \mathrm{M}$ oxalic acid (20:80), provides good resolutions of the three TCs (Figure 1A).

Plotting the ratio of peak area of the standards generated the calibration curve. Within the concentration range studied, 100$1000 \mathrm{ng} / \mathrm{g}$, linear plots were obtained for OTC, TC, and CTC. 
The mean correlation coefficients obtained were 0.9991, 0.9990, and 0.9987 for OTC, TC, and CTC, respectively.

Fluorescence detection is a valuable tool for tetracycline residue analysis. Owing to its specificity, intereferences from food components are reduced. Tetracyclines are separated on a reversed-phase $\mathrm{C}_{8}$ column and are made to react with magnesium acetate in boric acid buffer ( $\mathrm{pH} 9.0)$ to produce a highly fluorescent complex (31).

Excitation and emission wavelengths were optimized so that the three tetracyclines gave comparable peak intensities and were very similar. The spectra of the products showed excitation and emission maximum at 385 and $488 \mathrm{~nm}$ for OTC, 380 and 499 $\mathrm{nm}$ for TC, and 385 and $502 \mathrm{~nm}$ for CTC, respectively. We have estimated the optimum excitation and emission wavelengths for the three tetracyclines at 385 and $500 \mathrm{~nm}$, respectively.

Postcolumn derivatization does not directly affect the chromatographic properties of the tetracyclines. However, the chemical reaction must be rapid on the chromatographic time scale to preserve the chromatographic behavior. Postcolumn derivatization also has the advantages that a separate sample treatment step is not required and that analytes are better separated from interferences prior to derivatization. The fluorescence response depends on the flow rate of postcolumn reagent, and in our study, this reached a maximum at $0.45 \mathrm{~mL} /$ min.

Extraction and Cleanup Procedures. Because of the polar nature of tetracyclines, they were extracted from tissues using pH 4.0 Na $\mathrm{NaDTA}_{2}$-Mac Ilvaine buffer, according to Oka et al.'s procedure (26). Their propensity to complex with inorganic ions, fortunately, is overcome by adding EDTA to the extracting solvents (32). The content calcium of the raw swine muscle and kidney weight is between 11 and $19 \mathrm{mg} / 100 \mathrm{~g}$ and does not interfere in the analysis.

The modifications to Oka et al.'s extraction procedure included an ultrasonic processing step, centrifugation at $2500 \mathrm{~g}$ according MacNeil et al. (8), and incorporation of TCA to the combined supernatants as an additional protein denaturing step. Addition of this step alleviated SPE column blockage and reduced chromatographic noise.

$\mathrm{C}_{18}$ sorbent presents several limitations: TCs readily chelate to metal ions and can lead to low and variable recoveries, probably because of the presence of trace metal impurities in the sorbent; the active silanol sites of the octadecylsilylated silica support material also interact with the polar groups of the TCs. This strong ion-exchange interaction of TCs with trace metals provides a challenge in using SPE because of low recoveries resulting from premature breakthrough of TCs during sample loading (7-8). Since they are polar compounds, they may be insufficiently retained. This reduced retention can result in lower recoveries because of analyte breakthrough during the sampleloading step (9).

Oka et al. (26) observed that it was necessary to have a pretreatment of the Sep-Pak $\mathrm{C}_{18}$ cartridges with $0.2 \mathrm{M}$ aqueous $\mathrm{Na}_{2}$ EDTA solution to elute the TCs from the cartridge with ethanol. However, this pretreatment was not effective for Varian Bond Elut cartridge and Baker $\mathrm{C}_{18}$ cartridge.

Previous work using silica-based SPE cartridges indicated that the addition of oxalic acid to the methanol eluent was essential for good recoveries of TCs (26). To avoid adding nonvolatile salts to the elution solvent, we evaluated the cartridges containing a macroporous polymer (poly(divinylbenzene-co- $N$-vinylpirrolidone) that exhibits both hydrophilic and lipophilic characteristics for these matrixes. This polymeric

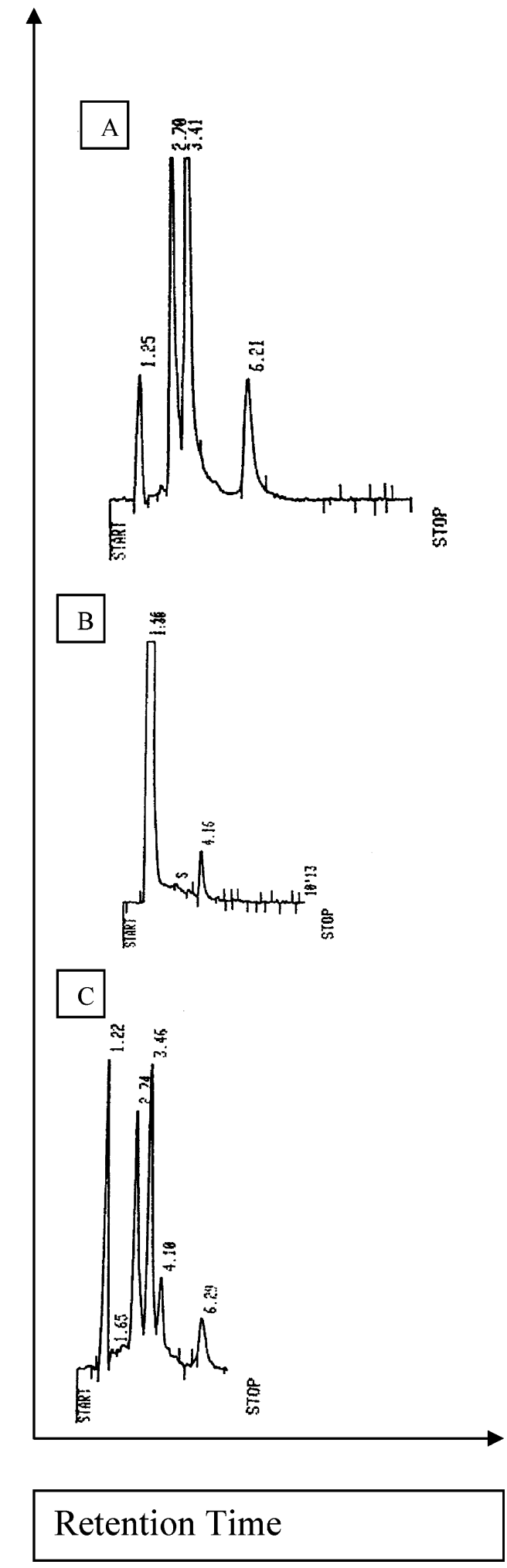

Figure 1. (A) Liquid chromatogram of standard solution of OTC, TC, and CTC. (B) Liquid chromatogram of blank kidney swine sample. (C) Liquid chromatogram of fortification assay kidney swine sample containing OTC, TC, and CTC.

presents several advantages, no impact of sorbent drying, no silanol interaction, and no breakthrough of polar analyte, and because it has a high retention capacity, we can use lower amounts of sorbent $(200 \mathrm{mg})$, which was was already applied successfully in our laboratory in TC analysis in salmon muscle (14) and honey (15). 
Table 1. Inter- and Intra-assay Validation Results

\begin{tabular}{|c|c|c|c|c|c|c|c|}
\hline sample & tetracyclines & number assays $(M)$ & fortification level & recovery variation (\%) & recovery mean (\%) & \%CV intraday & \%CV interday \\
\hline swine muscle tissue & $\begin{array}{l}\text { OTC } \\
\text { TC } \\
\text { OTC } \\
\text { TC } \\
\text { CTC } \\
\text { OTC } \\
\text { TC } \\
\text { CTC }\end{array}$ & $\begin{array}{l}5 \\
5 \\
5 \\
5 \\
5 \\
5 \\
5 \\
5\end{array}$ & $\begin{array}{r}50 \mu \mathrm{g} / \mathrm{kg} \\
50 \mu \mathrm{g} / \mathrm{kg} \\
100 \mu \mathrm{g} / \mathrm{kg} \\
100 \mu \mathrm{g} / \mathrm{kg} \\
100 \mu \mathrm{g} / \mathrm{kg} \\
200 \mu \mathrm{g} / \mathrm{kg} \\
200 \mu \mathrm{g} / \mathrm{kg} \\
200 \mu \mathrm{g} / \mathrm{kg}\end{array}$ & $\begin{array}{l}78.6-82.1 \\
77.8-81.8 \\
84.9-88.4 \\
83.3-85.9 \\
79.0-82.5 \\
80.1-88.9 \\
79.9-90.0 \\
79.0-84.3\end{array}$ & $\begin{array}{l}81.0 \\
80.7 \\
86.7 \\
84.6 \\
81.3 \\
85.6 \\
85.0 \\
80.4\end{array}$ & $\begin{array}{r}8.50 \\
9.14 \\
5.11 \\
6.23 \\
7.21 \\
7.00 \\
6.44 \\
11.28\end{array}$ & $\begin{array}{r}9.66 \\
9.89 \\
6.46 \\
7.27 \\
8.69 \\
6.00 \\
7.34 \\
10.31\end{array}$ \\
\hline swine kidney tissue & $\begin{array}{l}\text { OTC } \\
\text { TC } \\
\text { CTC } \\
\text { OTC } \\
\text { TC } \\
\text { CTC } \\
\text { OTC } \\
\text { TC } \\
\text { CTC }\end{array}$ & $\begin{array}{l}5 \\
5 \\
5 \\
5 \\
5 \\
5 \\
5 \\
5 \\
5\end{array}$ & $\begin{array}{l}100 \mu \mathrm{g} / \mathrm{kg} \\
100 \mu \mathrm{g} / \mathrm{kg} \\
100 \mu \mathrm{g} / \mathrm{kg} \\
200 \mu \mathrm{g} / \mathrm{kg} \\
200 \mu \mathrm{g} / \mathrm{kg} \\
200 \mu \mathrm{g} / \mathrm{kg} \\
600 \mu \mathrm{g} / \mathrm{kg} \\
600 \mu \mathrm{g} / \mathrm{kg} \\
600 \mu \mathrm{g} / \mathrm{kg}\end{array}$ & $\begin{array}{l}72.7-79.0 \\
73.9-77.5 \\
65.1-77.6 \\
80.5-82.0 \\
78.9-80.4 \\
70.0-79.3 \\
79.0-81.1 \\
77.7-83.5 \\
69.8-80.0\end{array}$ & $\begin{array}{l}77.6 \\
74.3 \\
71.0 \\
81.6 \\
79.5 \\
74.3 \\
80.3 \\
80.9 \\
76.5\end{array}$ & $\begin{array}{r}9.96 \\
9.78 \\
11.66 \\
6.90 \\
7.25 \\
8.87 \\
6.10 \\
6.78 \\
9.31\end{array}$ & $\begin{array}{r}11.36 \\
12.55 \\
14.32 \\
9.61 \\
11.30 \\
13.59 \\
10.00 \\
12.38 \\
13.88\end{array}$ \\
\hline
\end{tabular}

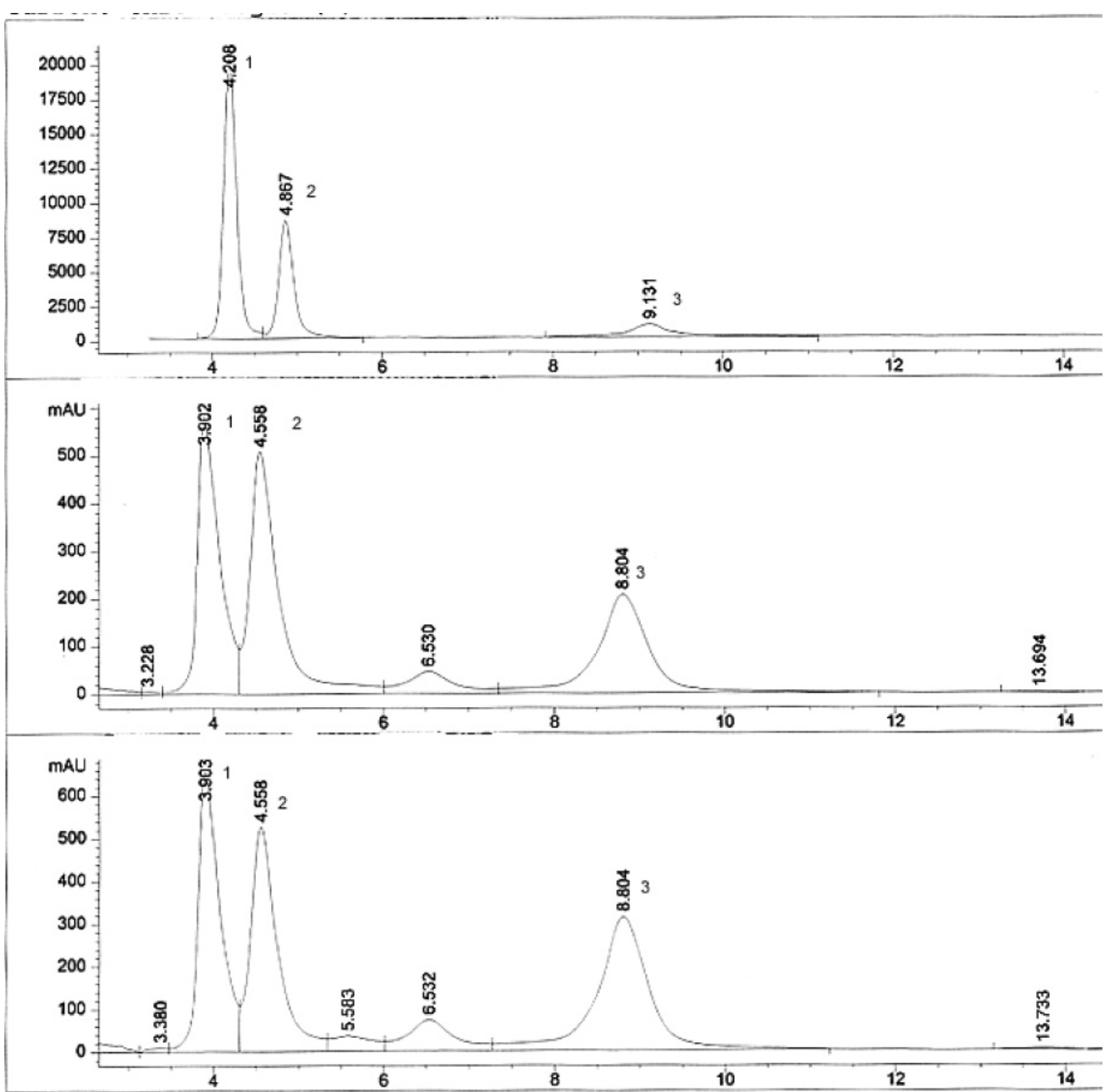

Figure 2. (A) LC-MS total ion chromatogram in positive ion mode under experimental conditions. 1-OTC, 2-TC, 3-CTC. (B) Diode array chromatogram at $360 \mathrm{~nm}$ under experimental conditions. 1-OTC, 2-TC, 3-CTC. (C) Diode array chromatogram at $254 \mathrm{~nm}$ under experimental conditions. 1-OTC, 2-TC, 3-CTC.

The chromatograms of the blank muscle and kidney swine extracts showed a clean one for the muscle and a small matrix peak on the kidney's chromatogram, in close proximity to the
CTC peak but clearly separated from it (Figure 1B). MacNeil (8) also noted that kidneys contained interfering substances that make it difficult to find a truly blank tissue. These interferences 


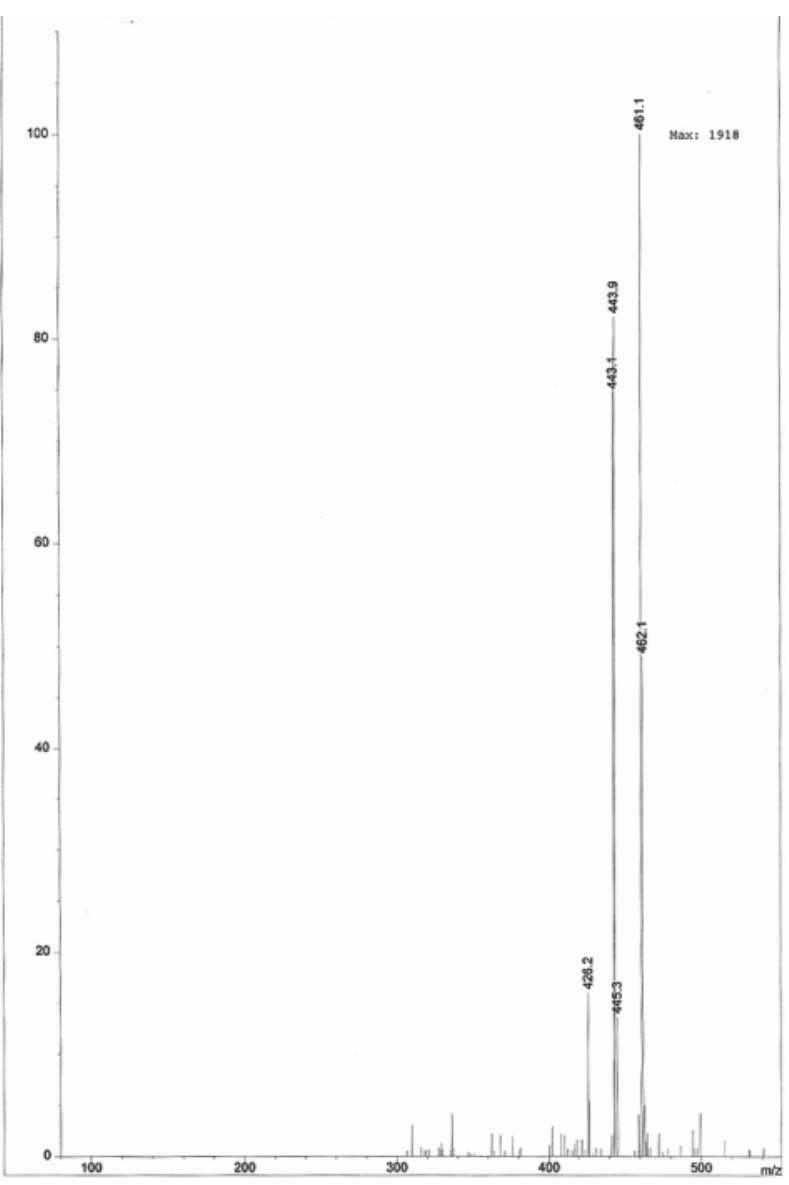

Figure 3. APCl mass spectra in positive ion mode of OTC.

seemed to be enhanced by additional tissue manipulations required to ensure homogeneity (8). Since this matrix peak does not interfere with the chromatographic analysis and was not present in mass spectrometric analysis when the selected ions were monitored under SIM mode, no additional cleanup step was attempted.

In the mass spectra of blank tissues, no ions corresponding to protonated molecular ion and typical fragment ions of TCs appeared.

Only $2 \mathrm{~mL}$ of methanol was necessary to elute TCs from the polymeric cartridge. We have proceeded to a second elution with another $2 \mathrm{~mL}$ of methanol, but no peaks were detected further. The concentration of the eluate at $35^{\circ} \mathrm{C}$ at low volume $(0.5-1.0 \mathrm{~mL})$ under gentle stream of nitrogen was also possible. Evaporation of sample extract to dryness was avoided since this could result in considerable losses of TCs (33).

The accuracy was evaluated by HPLC with spectrofluorometric detection at $\lambda_{\mathrm{ex}} 385 \mathrm{~nm}$ and $\lambda_{\mathrm{em}} 500 \mathrm{~nm}$ by spiking swine blank tissues at three fortification levels (one-half to twice the MRL), 50, 100, and $200 \mu \mathrm{g} / \mathrm{kg}$ for muscle and 100, 200, and $600 \mu \mathrm{g} / \mathrm{kg}$ for kidney tissues (Figure 1C).

Intraday and interday accuracy and precision data were obtained by performing extraction batches of the spiked samples and one blank (to check interferences) and by analyzing them, on the same day and on different days, respectively, against a calibration curve. Recoveries were generally greater than $77.8 \%$ for muscle and greater than $65.1 \%$ for kidney tissues, showing the good accuracy of the method. The coefficient of variation (CV) of intraday precision ranged from 5.1 and $11.6 \%$ and interday precision ranged from 6.0 and $14.3 \%$, showing a good repeatability (Table 1).

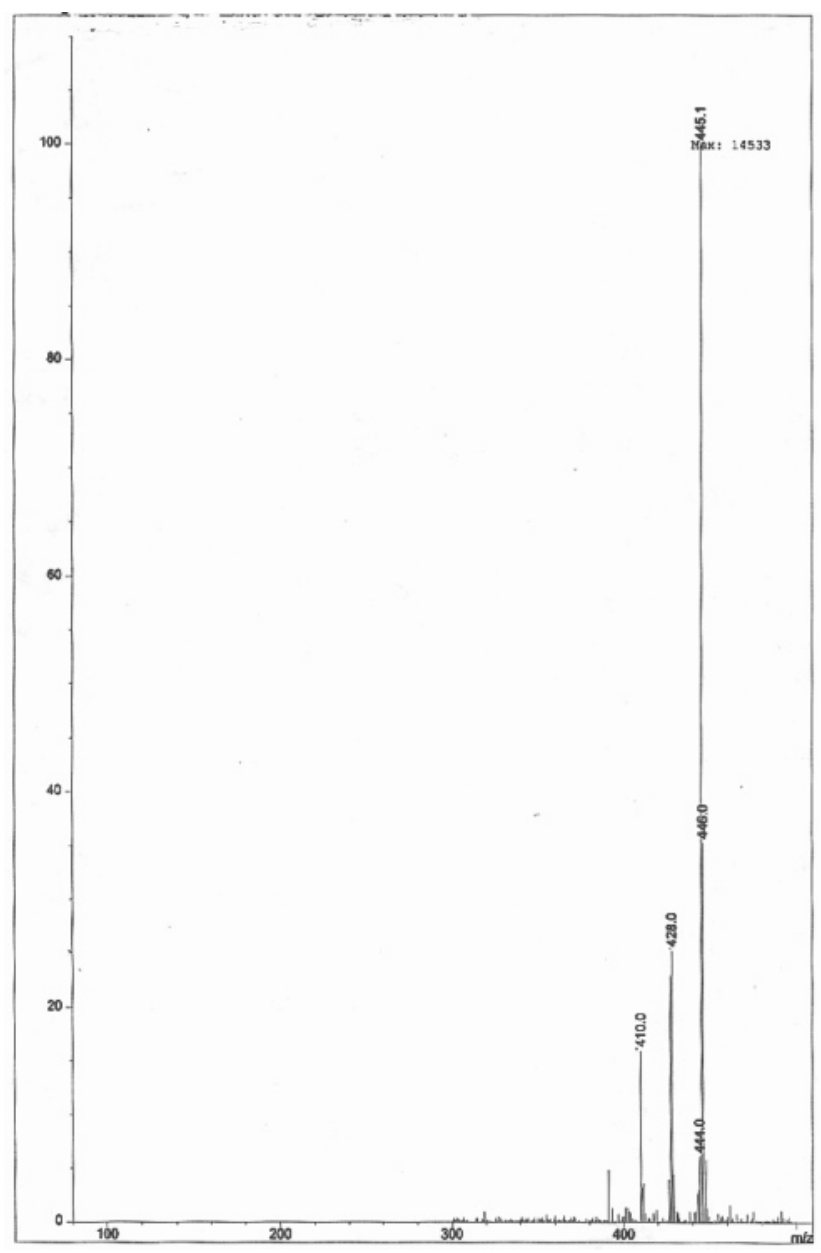

Figure 4. APCl mass spectra in positive ion mode of TC.

The 25 samples were collected from slaughterhouses along a 1 month period in the central region of Portugal. It was detected by LC with spectrofluorometric detection, the presence of OTC residue at violative level $(193.0 \mu \mathrm{g} / \mathrm{kg})$ in one muscle sample, and it was confirmed by LC-APCI-MS.

Confirmation by LC-APCI-MS. The use of a well endcapped silica gel column (Inertsil $\mathrm{C}_{18}$ ODS-2) enables the separation of the TCs without reduction of peak resolution using a volatile mobile phase, acetonitrile- $0.001 \mathrm{M}$ TFA $(20: 80, \mathrm{pH}$ 2.0), which is applicable to direct interface LC-APCI-MS without clogging problems, buildup of deposits in the ion source, and reduction in ion production.

Since good resolution of OTC, TC, and CTC was obtained (Figure 2), the use of oxalic acid was not investigated preferring not to introduce nonvolatile compounds into the mass spectrometer.

The system allows the determination by DAD and APCI to permit a simultaneous detection of TCs. The diode array detection was carried out at two wavelengths, 245 and $360 \mathrm{~nm}$, according to the maximum absorption of TCs.

To obtain optimal APCI conditions for TCs, the APCI mass spectra of TCs were measured under different conditions and the intensity of these ions was carefully observed. Adjustment of the voltage across the fragmentor induced sufficient fragmentation to permit the monitoring of at least three ions, very useful for confirmation (28-29).

The positive ion APCI mass spectra of TCs at a fragmentor voltage of $90 \mathrm{~V}$ show the protonated molecular ion as the peak base for OTC, TC, and CTC. The fragment ions $[\mathrm{M}+\mathrm{H}-$ 


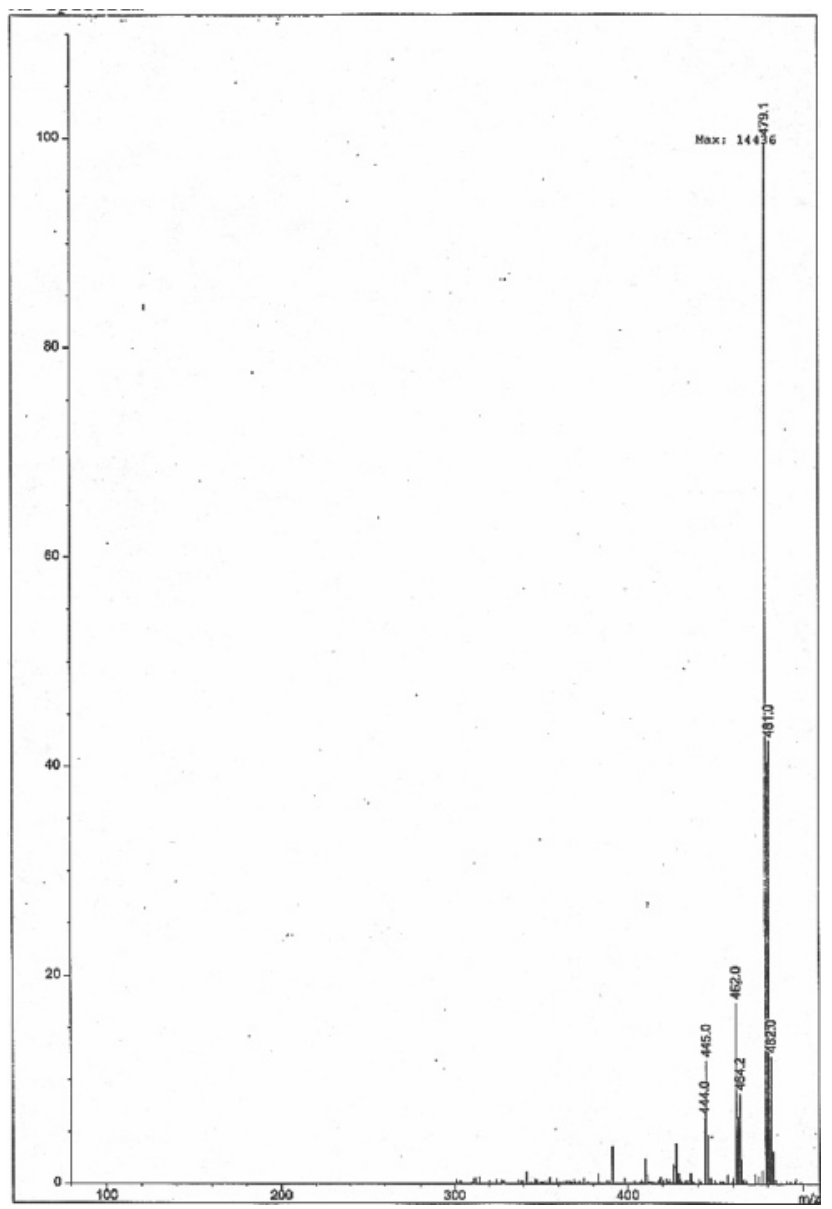

Figure 5. APCI mass spectra in positive ion mode of CTC.

Table 2. Molecular and Fragments lons Produced Using Positive Ion HPLC-APCI-MS

\begin{tabular}{|c|c|c|c|c|}
\hline tetracyclines & {$[\mathrm{M}+\mathrm{H}]^{+}$} & $\begin{array}{c}{[\mathrm{M}+\mathrm{H}-} \\
\left.\mathrm{NH}_{3}\right]^{+}\end{array}$ & $\begin{array}{c}{[\mathrm{M}+\mathrm{H}-} \\
\left.\mathrm{H}_{2} \mathrm{O}\right]^{+}\end{array}$ & $\begin{array}{c}{\left[\mathrm{M}+\mathrm{H}-\mathrm{NH}_{3}-\right.} \\
\left.\mathrm{H}_{2} \mathrm{O}\right]^{+}\end{array}$ \\
\hline OTC $^{a}$ & 461 & 444 & 443 & 426 \\
\hline TC & 445 & 428 & 427 & 410 \\
\hline CTC & $479,481^{b}$ & 462 & 461 & 444 \\
\hline
\end{tabular}

${ }^{a}$ OTC, oxytetracycline; TC, tetracycline; CTC, chlortetracycline. ${ }^{b}$ Chlorine isotopic ion.

$\left.\mathrm{NH}_{3}\right]^{+},\left[\mathrm{M}+\mathrm{H}-\mathrm{H}_{2} \mathrm{O}\right]^{+}$, and $\left[\mathrm{M}+\mathrm{H}-\mathrm{NH}_{3}-\mathrm{H}_{2} \mathrm{O}\right]^{+}$were observed in the mass spectra of the three TCs studied (Figures 3-5). In the mass spectra of CTC, typical chlorine isotopic ion is clearly observed (Figure 5).

The loss of ammonia occurs from the carboxyamide moiety in the A ring of TCs, and the formation of the $\left[\mathrm{M}+\mathrm{H}-\mathrm{NH}_{3}\right.$ $\left.-\mathrm{H}_{2} \mathrm{O}\right]^{+}$fragment ion is related on the presence of a hydroxyl group in the $\mathrm{C}$ ring. In the mass spectra obtained, the three compounds did not generate an $\left[\mathrm{M}+\mathrm{H}-2 \mathrm{H}_{2} \mathrm{O}\right]^{+}$ion, but there is evidence in the literature of tetracycline class compound generating this ion (13). Molecular and characteristics fragments ions obtained are summarized in Table 2.

When a higher fragmentor voltage was applied $(110 \mathrm{~V})$, a low abundance protonted molecular ion was observed and [M $\left.+\mathrm{H}-\mathrm{NH}_{3}-\mathrm{H}_{2} \mathrm{O}\right]^{+}$for OTC $(\mathrm{m} / \mathrm{z}, 426)$, TC $(\mathrm{m} / \mathrm{z}, 410)$, and the $\left[\mathrm{M}+\mathrm{H}-\mathrm{NH}_{3}\right]^{+}$for CTC $(\mathrm{m} / \mathrm{z}$ 462) appeared as the most abundant ions. This study was carried out with a fragmentor voltage of $90 \mathrm{~V}$.

The confirmation was based on SIM at three ions per tetracycline, for example, $\mathrm{m} / \mathrm{z} 461, \mathrm{~m} / \mathrm{z} 444$, and $\mathrm{m} / \mathrm{z}, 426$ for
OTC; $\mathrm{m} / \mathrm{z} 445, \mathrm{~m} / \mathrm{z} 428$, and $\mathrm{m} / \mathrm{z} 410$ for TC; and $\mathrm{m} / \mathrm{z} 479, \mathrm{~m} / \mathrm{z}$ $462, \mathrm{~m} / \mathrm{z} 444$, and the chlorine isotopic ion $\mathrm{m} / \mathrm{z} 481$ for CTC, and on the requirement to have relative abundances of these ions within $10 \%$ of the values obtained by standards (34).

Residue confirmation was based on analysis of the APCI mass spectra at the retention time of standards. To ensure adequate retention time matching, sample analyses were preceded and followed with standard analysis.

The curve of calibration exhibited good linearity and reproducibility over the calibration range for OTC, TC, and CTC. The regression coefficients were 0.9993, 0.9979, and 0.9990 for OTC, TC, and CTC, respectively.

The quantification limit obtained for OTC by APCI LC-MS was $100 \mu \mathrm{g} / \mathrm{kg}$, and the proposed method can reliably identify OTC in one muscle tissue sample at violative level.

In conclusion, the cleanup method outlined above with Oasis HLB copolymer is simpler relative to silica-based sorbents and leads to good recoveries for the determination of tetracycline residues in muscle and kidney swine tissues. Quantification at $50 \mu \mathrm{g} / \mathrm{kg}$ for muscle and at $100 \mu \mathrm{g} / \mathrm{kg}$ for kidney swine tissues by HPLC with spectrofluorometric detection was readily achieved. Absence of a peak of the appropriate retention time provides unequivocal evidence that an analyte is not present above the detection limits of the spectrofluorometric method.

The method by LC-APCI-MS has been successfully applied to the identification of OTC in one muscle swine sample that was previously found by LC with spectrofluorometric detection.

\section{LITERATURE CITED}

(1) Emborg, H.-D. Relations between the occurrence of resistance to antimicrobial growth promoters among Enterococcus faecium isolated from broilers and broiler meat. Int. J. Food Microbiol. 2003, 84, 273-284.

(2) European Community (EC) Regulation n² 2316/98, October 26, 1998.

(3) Anderson., C. R.; Rupp, H. S.; Wu, W.-H. Complexities in tetracycline analysis - chemistry, matrix extraction, cleanup, and liquid chromatography. J. Chromatogr., A 2005, 1075, 23-32.

(4) Lu, H.-T.; Jiang., Y.; Li., H.-B.; Chen, F.; Wong, M.-H. Simultaneous Determination of Oxytetracycline, Doxycycline, Tetracycline and Chlortetracycline in Tetracycline Antibiotics by High-Performance Liquid Chromatography with Fluorescence Detection. Chromatographia 2004, 60, 259-264.

(5) Caro, E.; Marcé, R. M.; Gormack, P.; Sherrington, D. C.; Borrull, F. Synthesis and application of an oxytetracycline imprinted polymer for the solid-phase extraction of tetracycline antibiotics. Anal. Chim. Acta 2005, 552, 81-86.

(6) Aoyama, R. G. High-performance liquid chromatographic analysis of oxytetracycline in Chinook salmon following administration of medicated feed. J. Chromatogr. 1991, 588, 181-186.

(7) Law, B.; Weir, S. Fundamental studies in reversed-phase liquid solid extraction of basic drugs. II: hydrogen bonding effects. $J$. Pharm. Biomed. Anal. 1992, 10, 167-179.

(8) MacNeil, J. D.; Martz, V. K.; Korsrud, G. O.; Salisbury, C. D. C.; Oka, H.; Epstein, R. L.; Barnes, C. J. Chlortetracycline, oxytetracycline and tetracycline in edible animal tissues, liquid chromatographic method: collaborative study. JAOAC Int. 1996, 79, 405-417.

(9) Croubels, S. M.; Vanoosthuyze, K. E. I.; Van Petegham, C. H. Use of metal chelate affinity chromatography and membranebased ion-exchange as clean-up procedure for trace residue analysis of tetracyclines in animal tissues and eggs. J. Chromatogr., A 1997, 690, 173-179.

(10) Cooper, A. D.; Stubbings, W, G. F.; Kelly, M.; Tarbin, J. A.; Farrington, W. H. H.; Shearer, G. Improved method for the online metal chelate affinity chromatography-high performance liquid chromatographic determination of tetracycline antibiotics in animal products. J. Chromatogr., A 1998, 812, 321-326. 
(11) Carson, M. C.; Ngoh, M. A.; Hadley, S. W. Confirmation of multiple tetracycline residues in milk and oxytetracycline in shrimp by liquid chromatographiy-particle beam mass spectrometry. J. Chromatogr., B 1998, 712, 113-128.

(12) Cheng, Y.-F.; Phillips, D. J.; Neue, U. Simple and rugged SPE method for the determination of tetracycline antibiotics in serum by HPLC using a volatile mobile phase. Chromatographia 1997, 44, 187-190.

(13) Zhu, J.; Snow, D. D.; Cassada, D. A.; Monson, S. J.; Spalding, R. F. Analysis of oxytetracycline, tetracycline, and chlortetracycline in water using solid-phase extraction and liquid chromatography-tandem mass spectrometry. J. Chromatogr., A 2001, 928, 177-186.

(14) Pena, A.; Lino, C. M.; Silveira, M. I. N. Determination of tetracycline antibiotics in salmon muscle by liquid chromatography using post-column derivatization with fluorescence detection. JAOAC Int. 2003, 86, 925-929.

(15) Pena, A.; Pelantova, N.; Lino, C. M.; Silveira, M. I.; Solich, P. Validation of an analytical methodology for determination of oxytetracycline and tetracycline residues in honey by HPLC with fluorescence detection. J. Agric. Food Chem. 2005, 53, 37843788.

(16) Kawata, S.; Sato, K.; Nishikawa, Y.; Iwama, K. Liquid chromatographic determination of oxytetracycline in swine tissues. JAOAC Int. 1996, 79, 1463-1465.

(17) McCracken, R. J.; John, W.; Blanchflower, W. J.; Hagaan, S. A.; Kennedy, D. G. Simultaneous determination of oxytetracycline, tetracycline and chlortetracycline in animal tissues using high-performance liquid chromatography post-column derivatization with aluminium and fluorescence detection. Analyst 1995, 120, 1763-1766.

(18) Voyksner, R. D.; Smith, C. S.; Knox, P. C. Optimization and application of particle beam high-performance liquid chromatography/mass spectrometry to compounds of pharmaceutical interest. Biol. Mass Spectrom. 1990, 19, 523-534.

(19) Kijak, P. J.; Leadbetter, M. G.; Thomas, M. H.; Thompson, E. A. Confirmation of oxytetracycline, tetracycline and chlortetracycline in milk by particle beam liquid chromatography/mass spectrometry. Biol. Mass Spectrom. 1991, 20, 789-795.

(20) Harada, K.-I.; Masuda, K.; Suzuki, M.; Oka, H.; Ikai, Y.; Hayakawa, J. Fast atom bombardment mass spectral study of tetracycline antibiotics. Org. Mass Spectrom. 1993, 28, 15121515.

(21) Blanchflower, W. J.; McCracken, R. J.; Haggan, A. S.; Kennedy, D. G. Confirmation assay for the determination of tetracycline, oxytetracycline, chlortetracycline and its isomers in muscle and kidney using liquid chromatography-mass spectrometry. $J$. Chromatogr., B 1997, 692, 351-360.

(22) Kamel, A. M.; Brown, P. R.; Munson, B. Electrospray ionization mass spectrometry of tetracycline, oxytetracycline, chlortetracycline, minocycline and methacycline. Anal. Chem. 1999, 71, 968-977.
(23) Oka, H.; Ito, K. Y.; Ikai, Y.; Kagami, T.; Harada, K.-I. Mass spectrometry analysis of tetracycline antibiotics in foods. $J$. Chromatogr., A 1998, 812, 309-319.

(24) Oka, H.; Ikai, Y.; Ito, Y.; Hayakawa, J.; Harada, K.-I.; Suzuki, M.; Odani, H.; Maeda, K. Improvement of chemical analysis of antibiotics XXIII: Identification of residual tetracyclines in bovine tissues by electrospray high-performance liquid chromatography-tandem mass spectrometry. J. Chromatogr., B 1997, 693, 337-344.

(25) Eeckhout, N. V.; Perez, J. C.; Claereboudt, J.; Vandeputte, R.; Petegham, C. V. Rapid Commun. Mass Spectrom. 2000, 14, 280-285.

(26) Oka, H.; Matsumoto, K.; Uno, K.; Karada, K.-I.; Kadowaki, S.; Suzuki, M. Improvement of chemical analysis of antibiotics VIII: Application of prepacked $\mathrm{C}_{18}$ cartridge for the analysis of tetracyclines residues in animal liver. J. Chromatogr. 1985, 325 , 265-274.

(27) Commission Decision 93/256/EEC. Off. J. Eur. Communities L118 1993, 64.

(28) Commission Decision of 12 August 2002 implementing Council Directive 96/23/EC concerning the performance of analytical methods and the interpretation of results (2002/657/EC). Off. $J$. Eur. Commun. 2002, L221/8.

(29) De Ruig, W. G.; Stephany, R. W.; Dijkstra, G. Criteria for detection of analytes in test samples. J. Assoc. Off. Anal. Chem. 1989, 72, 487-490.

(30) Pena, A.; Lino, C. M.; Silveira, M. I. Determination of oxytetracycline, tetracycline and chlortetracycline in milk. JAOAC Int. 1999, 82, 55-60.

(31) Haagsma, N.; Sherpenisse, P. High-performance liquid chromatographic determination of tetracyclines in animal tissues and eggs. In Proceedings of Euroresidue II, Conference on Residues of Veterinary Drugs in Food; Haagsma, H., Ruiter, A., CzedikEysenberg, P. B., Eds.; Veldhoven, The Netherlands, 1993; Vol. 2, pp 342-346.

(32) Oka, H.; Patterson, J. Chemical analysis of tetracycline antibiotics. In Chemical Analysis for Antibiotic Used in Agriculture; Oka, H., Nakazawa, H., Harada, K., MacNeil, J. D., Eds.; U.S.A. J. AOAC International: Arlington, VA, 1995; chapter 10, pp 333-405.

(33) Bouvier, E. S. P.; Martin, D. M.; Iraneta, P. C.; Capparella, M.; Cheng, D.; Phillips, J. LC-GC Int. 1997, 10, 577-585.

(34) Niessen, W. M. A. Analysis of antibiotics by liquid chromatography-mass spectrometry. J. Chromatogr., A 1998, 812, 5358 .

Received for review February 12, 2007. Revised manuscript received April 21, 2007. Accepted April 23, 2007. The authors thank FCT (Fundação para a Ciência e Tecnologia) and POCTI/FEDER for financial support for this project.

JF070398J 